\title{
Yoga Within
}

\author{
Viviana Siddhi* \\ Slovenian-born artist, NGO Mandala Transformation, USA
}

*Corresponding author: Viviana Siddhi, Slovenian-born artist with American citizenship, NGO Mandala Transformation, Inc., California, USA.

Received Date: August 26, 2019

Published Date: September 06, 2019

\section{Short Communication}

The yogis say that we were not born merely to be subject of pain, suffering, disease, stress and death. The spiritual investigation of life's purposes requires keen intellect and strong will, products of a healthy body and mind.

In ancient writings the heart as an organ enjoys less importance than heart as the seat of sensation and consciousness. One does not know to what extent the much-publicized feast of control of the Yogi of the heart are related to the control of the heart as an organ. It is more likely that the concept of heart as the seat of sensations and consciousness is meant here e.g. Hrdaya Cit Samvit (knowing the mind through the heart) and vice versa controlling the heart through the mind (Kaya Sampat).

We are human beings that need to be nourished on all levels that we can efficiently cope with a daily life. The system of yoga involves proper exercise, proper breathing, proper relaxation, proper diet, positive thinking, and meditation. Mental process of cleansing the nadis is very important. If we have impurities in our bodies, we have negative thoughts. If we have negative thoughts, we get use to express ourselves in negative ways. Negative thoughts and words are leading us into negative actions. It's very easy to be lost in illusions. Only clarity brings will power and determination. Tension, negative emotions and depression can be overcome with advanced breathing exercises and purifying nadis.

Where are nadis located in the body? "Within the Sushumna extends from Muladhara Chakra, which is located in the second vertebra of the coccygeal region, to the Brahmarandhra or opening of the skull. Western anatomy admits that there is a central canal in the spinal cord called "canalis centralis", and that this cord is made up of grey and white brain matter. The Sushumna pierces all lotuses and is pure intelligence. One can meditate upon the Sushumna as if it were a chain of lightning of extremely subtle fiber as in a lotus. Within the Sushumna there is a Nadi by the name of Vajra that is as lustrous as the sun with rajasic qualities. Within Vajra Nadi, there is another Nadi, the Chitra. It is of sattvic nature and pale color.
Within the Chitra, there is a very fine minute canal through which the kundalini when awakened passes from the Muladhara to the Sahasrara Chakra. In this canal exists all the main chalras or lotuses each representing a different state of consciousness" [1].

A technique that has been utilized by Yogis for thousands of years is the Nadi Shodhana Pranayama techique. When our nadi's are clean and open, the prana can flow smoothly, and we are energized and healthy. Purifying nadis has several steps. One of them is following:

“1. Sit in padmasana or sidhasana (adept's position). Meditate on the root syllable or (bijakshara) air (vayu), YAM that is of smoke colour. Inhale through the left nostril repeating sixteen times the root syllable YAM. Retain the breath as you repeat YAM sixty-four times. This is retention. Then exhale through the right nostril very slowly as you repeat YAM thirty-two times" [2].

"Scientists have discovered that this nasal function also corresponds with brain function. According to Yogic teaching, alternative nostril breathing is derived from an awareness that the normal human breathing cycle alternates between the right and left nostrils every two hours. Scientists have discovered that this nasal function also corresponds with brain function. According to research, activity of the brain is found to be much greater in the side opposite the nostril with less congestion or blockage. These blockages impact the natural brain function. Furthermore, form biology class, you may recall that the right side of the brain controls creative activity while the left side controls verbal and logical activity. Practice of Nadi Shodhana has been shown to regulate the activity across both sides of the brain, by imposing brain activity. Through an imposing of regularity on the brain and mental processes, a related effect is seen throughout other autonomous body functions as well.

An end result of this practice is a "balance" across many body functions and emotions. Effects may include: 
- Balance across tendencies towards introversion and extroversion

- Balance across the desire to act and actual action

- Balance across creative and logical thought patterns

- Increased feeling of peace and happiness

- Increased feeling of purpose

- Increased feeling of motivation

- Increased and more sustained levels of energy" [3].

This is first stage of purifying and is only for advanced students who have been initiated by their teacher.

Ancient people have known for centuries that water, earth, fire and air purify our energy. Balanced diet is essential for a balanced body, mind and the spirit.

Active and effective people tend to find life an adventure, enjoy variety and always seem to end up enriched. On the other hand, passive and ineffective people seem always to be in a state inadequate adjustment to the unsatisfactory nature of things. Active people make better and dynamic leaders. The real test of a leader comes when a chosen course of action has to be implemented in the face of difficulties, discouragements, criticism, adversity and human failures. In such situations it is character that helps a leader to stay the course. Self-knowledge is the steeping-stone for selfimprovement, and it should be consequently handled.

"Indifference to worldly pleasures is vairagya (dispassion). This world is nothing but a mirage. As there is no true happiness, you want to find the eternal happiness that is within you (you are that happiness). Until you have that dispassion, you will not be able to put full effort behind your Yoga practice, so that eventually your vairagya will dissipate, causing you to go back into your old ruts: drinking, smoking, etc. Therefore, you must truly realize that all this drinking and smoking will bring you pain and disease, and you must wish to escape from this" [4].

Trying to be at every occasion happy is not a solution. It can be a cover for the problem instead to focus on solutions. If we understand that knowing our own strengths and weaknesses is essential for self-development, then there is quite a bit that we can do ourselves. Inability to look at ourselves with detachment puts us "on a self-deceiving, self-justifying" path often involving rational lies to self and others. In the bargain, people injure themselves deeply and struggle through life, blaming others.

"Materialistic civilization has made man insincere and untruthful. Falsehood and duplicity are the accepted codes of conduct in international relations. People speak of a "New Order". The New Order will only come when we have more man with vision of truth, sympathy, hearts of love, compassion, understanding, selfcontrol and self-effacement" [5].

"The traditional Yogi with a heightened awareness understood the human body not so much through dissection and visual means as by precise awareness and attention-playing as if by ear. When Goraksanath asks as to how one can who does not know the working of his own body achieve success, Goraksanath refers to this deep inner understanding.

Mind itself is the cause of diseases and also of its cure. Though it is generally believed that there are some diseases like cancer which are not caused by the mind, recently it has been found that gradually we are inching closer and closer to the proposition that the mind caused all the disease" [6].

The best method of knowing ourselves is to look at us in deep silence and ask questions about ourselves. Our sub-consciousness will give us the right answers. If we examine our motives behind our thoughts, words and actions, then we start understanding ourselves. Here are some examples of questions of self-examination:

- Are my thoughts, words and actions always pure? Was there an occasion recently when it was not so?

- Can I be considered to be a person of integrity - acting according to what is expecting of me in my position?

- Am I honest?

- Am I loyal?

- Do I have faith?

- Do I have patience and persistence to apply myself to a task till it is successfully completed?

- Do I know my strengths and weakness?

"Yoga enjoins knowledge of the working of the body, mind and spirit. "Know Thyself" is what is enjoined in Yoga" [7].

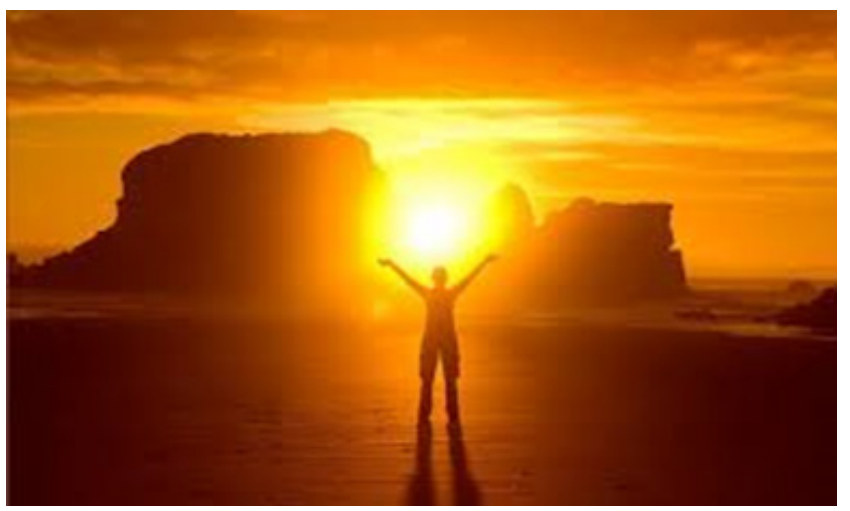

The most important act of courage for a leader is to make decisions. No action can start unless a decision is made. To make a decision means being accountable for success or failure, that is why large number of people procrastinates. Most decisions have to be made in an atmosphere of uncertainty of the outcome. We have to remember that nothing happens without decision. That is why it is said that a bad decision is bad decision is better than no decision at all. One who is courageous will not lie. It requires courage to punish. Compassion is made an alibi for the lack of courage.

When we are in balance, we are able to take good decisions. One of the Yoga Asanas that brings mental benefits and it regulates moods, emotions and stress is "Fish". One, who practices the Headstand on daily base, stays young and healthy. "He who practices the Headstand for three hours daily conquers time" [8]. If we invest in our transformation, then we shall acquire lifelong inspiration to 
grow and become the masters of our destiny.

Will power is the king of all faculties? In the implementation of any plan, program or project, hundreds of difficulties arise. Failure is due to natural causes; at times these are due to insufficient resources; at times, these are due to fragilities of human nature. Will power to persist in spite of setbacks and difficulties that may arise are necessary. The experience of research and experiments indicates that almost everybody is anxious to improve himself. Unfortunately, those of us who stay the course to change and transform our habits of thoughts, word and action are less than $15 \%$.

"Anger and lust are the two inner enemies that stand in the way of developing Bhakti. From lust follow the ten vices that are mentioned in Manusamhita - love of hunting, gambling, sleeping by day, slandering, company with bad women, drinking, singing lovesongs, vulgar music, dancing, aimlessly wandering about.

Anger begets eight kinds of vices. All evil qualities proceed from anger. If you can eradicate anger all bad qualities will die of themselves. The eight vices are: injustice, rashness, persecution, jealousy, taking possession of others' property, harsh words and cruelty" [9].

An example of will power is determination. Nothing in the world can take the place of persistence. He who has the necessary will power can become the master of his destiny. This quality is the key to self-development. If it is strengthened and reinforced, then transforming our character becomes an achievable goal. Transforming means getting rid of our bad habits, situations, and relationships.
"The British writer Aldous Huxley was a successful student and enthusiastic admirer of Dr. Bates' method. After using his exercises to recover from a condition of near-blindness, Huxley wrote a book called The Art of Seeing, in which he described seeing as a threestep process involving the eyes, the brain, and the mind" [10].

\section{Acknowledgment}

None.

\section{Conflicts of Interest}

No conflict of interest.

\section{References}

1. (1989) Sivananda Yoga Teachers Manual. True World Order by International Sivananda Yoga Vedanta Centres, Canada, pp.23.

2. (2005) Sivananda Sadhana Intensive Manual. Sivananda Yoga Vedanta Centres, Canada, pp.40.

3. Ravi Raman (2015) The Cleansing Power of Breath. Enterprise LLC.

4. Yogi Svatmarama (2008) Hatha Yoga Pradipika. Motilal Banarsidass Publishers, India, pp.131.

5. Swami Sivananda (2008) Himalaya Jyoti. The Divine Life Society, Uttarakhand, Himalayas, India, pp.75.

6. Armaiti N Desai Hansa Jayadeva Yogendra (2011) Heart Care. India, pp.1.

7. Jayadeva Yogendra 2008 Yogic Life. Yogendra Publication Fund, India, pp. Introduction.

8. (1991) The Sivananda Yoga Sivananda Yoga Vedanta Centre. Yoga Tatwa Upanishad, Canada, pp.27.

9. (2013) Yoga in Daily Life Swami Sivananda. The Divine Life Society, India, pp.39

10. (1999) Yoga for Your Eyes Meir Schneider. Sounds True, USA, pp.8. 